\title{
Is Post Earnings Announcement Drift A Priced Risk Factor in Emerging Markets? Chinese evidence
}

\author{
Amanda Man Li \\ Business School \\ University of Western Australia \\ Michael Dempsey \\ School of Economics, Finance and Marketing \\ RMIT University
}

\begin{abstract}
This study examines the profitability of trading on earnings surprises in the postearnings announcement period for equities listed in the Shanghai and Shenzhen stock exchanges spanning the period 2000 to 2008 when Chinese markets were developing. The paper also examines whether the drift is a priced risk factor. We show that a postearnings announcement drift (PEAD) anomaly exists in China. We document that a hedge strategy of going long on stocks in the highest earnings surprise decile and going short on firms in the lowest earnings surprise decile generates $7.92 \%$ excess return in the 60 days following the earnings announcement. We also show that the PEAD is a priced risk factor. Our paper is the first to document that PEAD is systematically priced as a risk factor in stock returns.
\end{abstract}

JEL classification: G11 G14 G15 M41

Keywords: Post-earnings announcement drift, Earnings surprise, Divergence of opinion, Asset pricing

\section{INTRODUCTION}

In this paper we examine the profitability of trading on earnings surprises in the post-earnings announcement period for equities listed in the Shanghai and Shenzhen stock exchanges spanning the period 2000 to 2008 . We also examine whether the PEAD is systematically priced as a risk factor in stock returns. We examine the significance of PEAD in the context of the onefactor and three-factor asset pricing models, as well as the enhanced one-factor and threefactor asset pricing models. We show that stock prices from the Chinese stock market have pronounced delayed reactions to earnings information. Specifically, a hedge strategy of going long the top decile of earnings surprise stocks and short the bottom decile of earnings surprise stocks can generate $7.92 \%$ excess return in the 60 days subsequent to earnings announcements. There is evidence that the magnitude of PEAD decreases in the level of market risk and increases in the level of trading volume as a proxy for transaction costs and liquidity. As far as the asset pricing tests are concerned we show that PEAD is a priced risk factor.

Post-earnings drift is the tendency for a stock's cumulative abnormal returns (CAR) to drift in the direction of a recent earnings surprise following an earnings announcement for several weeks or months (Linvnat and Mendenhall 2006). Since Ball and Brown (1968) first identified PEAD, a number of studies have confirmed the existence of PEAD in US markets. ${ }^{1}$ Numerous 
studies have attempted to explain the PEAD giving rise to three possible explanations. The first explanation is related to methodological shortcomings (Jacob et al. 2000; Livnat et al. 2006). The second explanation suggests investors' under-reaction to earnings announcement; that is, PEAD is caused by investors' underestimation of the significance of current earnings for future earnings (Foster, 1977; Bernard and Thomas 1990; Ball and Bartov, 1996). The third explanation suggests that PEAD is caused by the misspecification of the asset pricing model used to compute the abnormal returns. Although the first two explanations are the sources of PEAD, some studies show that, even after correction for methodology and investor underreaction, the PEAD still remains. For example, Fama (1998) investigates market anomalies, and describes PEAD as the "granddaddy of under-reaction events"; more importantly, he argues that market efficiency survives the challenge from this anomaly by claiming that underreactions are just as frequent as overreactions in an efficient market. In a more recent paper, Richardson et al.(2010) argue that PEAD is not only one of the most researched accounting anomalies in academic area, it is also a popular trading strategy of the US institutional investors.

In contrast to the voluminous PEAD research in the US, there has been only limited research relating to non-US markets. Booth et al. $(1996,1997)$ show that PEAD is higher for positive earnings surprise than for negative earnings surprise in Finnish stock market. They relate PEAD to some unique features of the Finnish market. Hew et al. (1996) and Liu et al. (2003) find that there are significant drifts following earnings announcements of UK firms. A recent study by Truong (2010) reports that PEAD does also exist in the New Zealand stock market over 1994 to 2008 and that PEAD is stronger for negative earnings surprise than for positive earnings surprise. Truong (2011) also shows that PEAD exists in China. Our study not only extends the existing literature on PEAD to one of the most important Asia-Pacific stock markets, the Chinese market, which provides an interesting setting in which to investigate the PEAD effect but more importantly makes an important contribution by examining whether the PEAD is a priced risk factor. None of the prior studies we are aware of have investigated the PEAD in an asset-pricing context.

This prompts the question - Why China for a study of developing markets? Due to its rapid growth and increasing significance in the global financial markets, researchers and investors have turned much of their attention to the Chinese market. Since the inception of the Chinese stock markets in 1990, the total capitalization of the Shanghai and Shenzhen rose from 10.77 billion RMB to around 15.07 trillion RMB by the end of 2008, and the number of listed firms increased from 13 to 1604 during the same period. We show the change of Chinese stock market index and the rapid development of the whole market in Figure 1 and Table 1, respectively. The rapid growth of the Chinese markets is caused by the steady flow of newly listed firms and the vast reduction of state-owned shares. Because almost all publicly listed firms in China were once SOEs, the ownership structure of former SOEs has led to a mixed ownership structure of listed firms with several types of shares and non-tradable shares dominate Chinese markets. ${ }^{2,3}$

\footnotetext{
The types of shares in the Chinese market are state shares and legal person shares owned by the central government, local governments, or government-owned enterprises, and which cannot be traded publicly; A shares, traded by domestic investors or Qualified Foreign Institutional Investors; and B shares issued to foreign investors (Sun and Tong, 2003). Chinese firms are also allowed to issue shares in overseas stock markets, such as $\mathrm{H}$ shares listed in the Hong Kong Stock Exchange and N shares listed in the New York Stock Exchange (Poon et al., 1998; Sun and Chong, 2007).
} 
Figure 1

The Shanghai and Shenzhen A-share market index, 1995-2008.

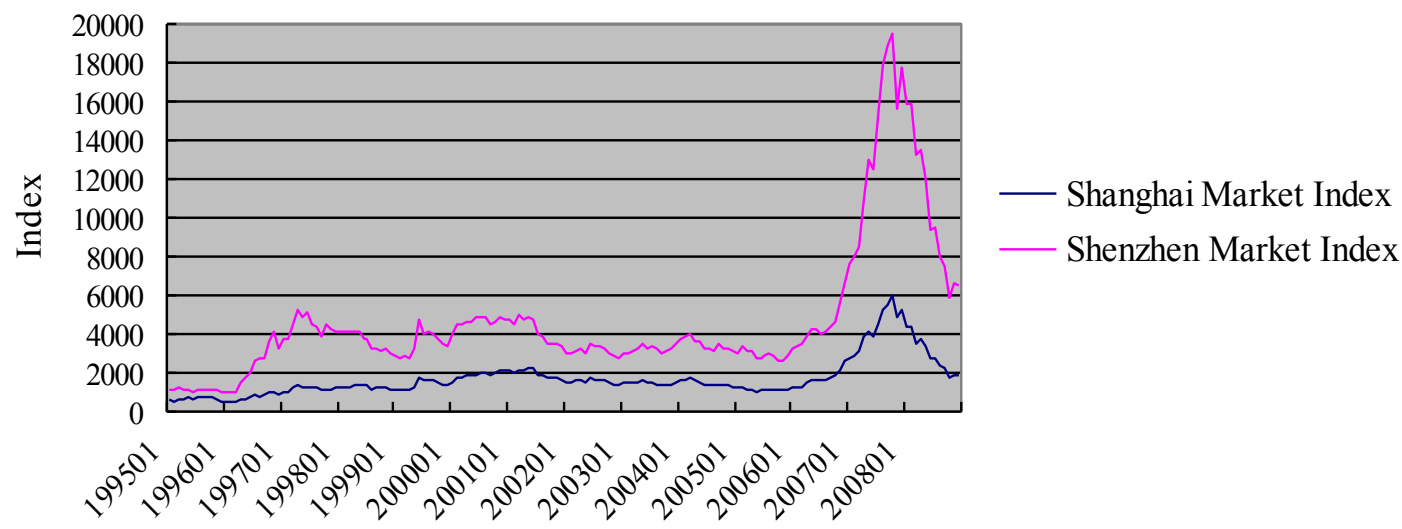

Year

Figure 1 provides an overview of the Shanghai and Shenzhen A-share market index over the time period January 1995 to December 2008

Table 1

Descriptive statistics for the Chinese A-share market over the period January 1995 to December 2008

\begin{tabular}{|c|c|c|c|c|c|}
\hline Year & $\begin{array}{c}\text { Number } \\
\text { of } \\
\text { listed } \\
\text { stocks }\end{array}$ & $\begin{array}{l}\text { Total market value } \\
\text { (in RMB, billions) }\end{array}$ & $\begin{array}{l}\text { Market value of tradable } \\
\text { shares (in RMB, billions) }\end{array}$ & $\begin{array}{l}\text { Trading } \\
\text { volume }\end{array}$ & $\begin{array}{l}\text { Value of shares traded } \\
\text { (in RMB, billions) }\end{array}$ \\
\hline 1995 & 287 & 333.78 & 79.68 & $68,095.67$ & $395,816.63$ \\
\hline 1996 & 311 & 952.87 & 252.20 & $246,511.49$ & $2,105,331.43$ \\
\hline 1997 & 514 & $1,731.66$ & 488.18 & $247,129.84$ & $3,029,521.18$ \\
\hline 1998 & 719 & $1,934.15$ & 554.78 & $209,159.57$ & $2,340,946.26$ \\
\hline 1999 & 825 & $2,630.52$ & 797.74 & $280,931.81$ & $3,104,367.78$ \\
\hline 2000 & 923 & $4,780.02$ & $1,555.06$ & $456,047.65$ & $6,029,815.75$ \\
\hline 2001 & 1060 & $4,254.66$ & $1,332.81$ & $246,836.40$ & $3,327,976.92$ \\
\hline 2002 & 1135 & $3,768.46$ & $1,177.06$ & $286,056.50$ & $2,714,820.76$ \\
\hline 2003 & 1198 & $4,168.22$ & $1,236.36$ & $399,015.12$ & $3,124,825.11$ \\
\hline 2004 & 1262 & $3,654.02$ & $1,106.64$ & $567,129.22$ & $4,156,695.77$ \\
\hline 2005 & 1350 & $3,184.68$ & $1,003.28$ & $646,893.54$ & $3,108,738.78$ \\
\hline 2006 & 1352 & $8,891.57$ & $2,384.67$ & $1,580,656.28$ & $8,920,308.17$ \\
\hline 2007 & 1390 & $32,556.24$ & $9,081.83$ & $3,568,212.49$ & $45,474,251.16$ \\
\hline 2008 & 1497 & $14,824.85$ & $4,458.56$ & $2,387,029.33$ & $26,551,492.14$ \\
\hline
\end{tabular}

The Chinese authorities made several attempts to release non-tradable shares to the public. The first two attempts in 1999 and 2001 failed badly. On April 29, 2005, the Chinese authorities launched a new structural reform program to encourage all A-share listed firms to gradually transform non-tradable shares into tradable shares. Prior to the non-tradable share reform in 2005, about two-thirds of China's shares were non-tradable (Beltratti and Bortolotti, 2006; Lu et al. 2008). Non-tradable shareholders are entitled to the same voting and cash flow rights as holders of tradable shares but they cannot trade their shares publicly (Poon et al., 1998; Li and Greco, 2006). 
This table provides an overview of the growth of the Chinese stock market from 1995 to 2008, including the number of listed firms, the total market capitalization of outstanding shares (tradable and non-tradable), the market capitalization of tradable shares, trading volume, and the value of shares traded.

Since the Chinese market has continued to reform since the late 1990s, the proportion of institutional investors has increased, including pension funds, mutual funds, and insurance companies. For example, closed-end funds became available as of 1998 and their number grew to 33 by the end of 2009, while open-end funds were issued starting in 2002 and increased to 335 by the end of 2009. Moreover, since 2000, the Chinese market has been open to international investors, who are referred to as qualified foreign institutional investors. However, institutional investors still play a limited role in the Chinese stock markets, such that short-term individual investors continue to dominate stock markets and limited investment instruments are available. The number of investor accounts has increased from 2.2 million to 79.73 million, $99.7 \%$ of the accounts being individual accounts and $0.3 \%$ are institutional accounts (http://www.szse.cn and http://www.sse.com.cn).

The average annual market turnover rate is 484\% over the period 1993-2007, which is much higher than the $100 \%$ turnover rate for actively managed funds in developed markets. Hence, this unique institutional setting challenges traditional financial theory and asset pricing models. Kang et al. (2002) find that China is one of the few countries that are negatively correlated with the US markets. Drew et al. (2003) document that average returns are negatively related to book-to-market equity. Gong (2003) argues that because of unique cultural background of Chinese investors, they behave differently from western investors. Chen et al. (2007) show that Chinese investors sell stocks that have increased in value and hold on to stocks that have been decreasing in value.

Naughton et al. (2008) also show that although price momentum is strong in the Shanghai market, past trading volume has little predictability in China. Specifically, our study is related to that of Garfinkel and Sokobin (2006) in that we define earnings surprise as abnormal returns and to measure opinion divergence which is unexplained volume, the difference between earnings announcement turnover and the turnover from a non-announcement period. Our study extends the Garfinkel and Sokobin (2006) study by using Chinese market data to examine whether PEAD is associated with divergence of opinion.

Regarding the impact of arbitrage risk on PEAD our study is related to Mendenhall (2004), who finds that the magnitude of PEAD is significantly positively related to the arbitrage risk, which also impedes arbitrageurs who attempt to profit from it. With regard to the impact of liquidity and transaction costs, our study is related to Mendenhall (2004), who use the closing stock price 20 days prior to earnings announcement (PRICE) and the daily closing price times daily shares traded averaged over -120 to -20 days relative to earnings announcements (VOLUME) as proxies for transaction cost and liquidity. Our study is closely related to a recent study by Truong (2011) who investigates the PEAD for Chinese stocks. However, our study is different from that study in several aspects: we include divergence of opinion as a potential factor to explain PEAD; more importantly, from an asset pricing point of view, we examine whether the PEAD is a priced risk factor in explaining stock returns in the Chinese market, which is a major contribution of our study.

Overall, we make two main contributions. First, we provide new evidence by investigating the PEAD for Chinese equities and thereby contribute to the literature on the PEAD anomaly in the 
context of an emerging market. We also examine the robustness of several factors that might determine the magnitude of PEAD. In doing so, we are the first to look at the relationship between the divergence of opinion and PEAD in China. This contributes to a better understanding of the nature of PEAD and the efficient market hypothesis. Our study is the first attempt to investigate whether the PEAD is a priced risk factor by constructing asset pricing models based on CAPM and Fama-French three-factor models and thereby contribute to riskbased explanations of stock price formation.

The remainder of this paper is organized as follows. Section 2 reviews the relevant literature and develops the motivation for this paper. Section 3 describes our data, methodology, variable definitions and research design. Section 4 presents empirical results and Section 5 concludes our study.

\section{PRIOR RESEARCH AND MOTIVATION}

As an empirical challenge to the semi-strong form of the EMH, the delay in stock price response to earnings announcement has been studied for four decades. Ball and Brown (1968) find abnormal returns before and after quarterly earnings announcements. Fama (1998) documents that "the granddaddy of underreaction events is the evidence that stock prices seem to respond to earnings for about a year after they are announced"(p.286), and he also states that "the post-earnings-announcement drift first reported by Ball and Brown (1968) has survived robustness checks, including extension to more recent data" (p.304). Subsequent studies have confirmed the significance of PEAD. ${ }^{4}$ For the US sample, the magnitude of the drift which is obtained by a Compustat time series model and analyst forecasts data. ${ }^{5}$ Some studies examine the PEAD anomaly in other stock markets. Booth et al. (1996) find that PEAD is stronger for firms that do not have smooth income series.

Booth et al. (1997) document that PEAD is stronger for firms that make significant adjustments for tax purposes. In the Finnish market, Finnish firms pay more attention to tax considerations, thus, earnings of firms that make significant tax adjustments are often larger because earnings need to be sufficiently large to allow for large depreciation. Using the Japanese sample, Mande and Kwak (1996) provide evidence of significant under-reaction among the analysts to earnings information. Griffin et al. (2008) confirm the profitability of PEAD strategy in several emerging markets. Troung (2010) shows that investors under-react to both analyst-based and time-series earnings surprise in New Zealand. Troung (2011) also provides convincing evidence that PEAD does exist in the Chinese market.

Although numerous studies confirm that PEAD exists, there is no consensus on what drives PEAD. A first potential explanation is focused on methodological shortcomings. For example, in the earliest PEAD papers, researchers use assumed rather than actual earnings announcement dates (Jones and Litzenberger 1970). Foster et al. (1984) avoid this problem by sorting stocks

See Jones and Litzenberger (1970), Brown and Kennelly (1972), Joy et al.(1977), Watts (1978), Foster et al.(1984), Rendleman et al.(1987), Bernard and Thomas (1989, 1990), Freeman and Tse (1989), Mendenhall (1991), Wiggins (1991), Bartov (1992), Bhushan (1994), Ball and Bartov (1996), and Bartov et al.(2000), among others.

Using time series forecasts, Rendleman et al. (1982), Foster et al. (1984) and Bernard and Thomas (1989) document a top surprise decile versus bottom decile drift of about 8-10 basis points per day-about 5-6\% per quarter from the 1970s to the 1980s. More recently, Collins and Hribar (2000) and Narayanamoorthy (2003) report two-quarter return differences of 7.1\% for 1988-1997 and 6\% for 1978-1998, respectively. Using analyst forecasts data, the magnitude of the drift is similar to that used in time series models. Abarbanell and Bernard (1992) find one- and two-quarter return differences of $4.98 \%$ and $7.02 \%$, respectively. Using I/B/E/S data, Liang (2003) estimates the 60-day drift to be approximately 6\% between 1989 and 2000. 
based on the prior quarter's earnings surprise. The second explanation is that there is an increase in risk of companies for higher expected returns in equilibrium (Ball et al., 1993). The third potential explanation follows, for example, Rendleman et al. (1987) Bernard and Thomas (1989), and Freeman and Tse (1989) argue that the drift may be caused by investors who underestimate the implications of current earnings for future earnings, particularly next quarter's earnings. The third explanation is investigated in the recent literature in the form of several hypotheses. Several important factors that may influence PEAD are explored.

\section{Arbitrage risk and PEAD}

The statistical and economical magnitude of PEAD should attract arbitrageurs, who see the PEAD anomaly as a trading opportunity. Thus, it is likely to ask why arbitrageurs do not make profits by arbitraging away the PEAD. Wurgler and Zhuravskaya (2002) provide a possible answer, namely, that the demand of the arbitrageur for a stock is inversely related to that stock's arbitrage risk. Using a theoretical model where arbitrageurs have access only to a small number of stocks, Shleifer and Vishny (1997) find that if investors underreact to earnings announcements, stocks with high idiosyncratic risk will be more mispriced and therefore have higher drifts. Mendenhall (2004) defines arbitrage risk as the idiosyncratic part of a stock's volatility that arbitrageurs cannot avoid by holding offsetting positions, and argues that PEAD is positively related to arbitrage risk.

\section{Transaction costs and PEAD}

Trading frictions, such as transaction costs, can make attractive trading profits unrealizable. Garman and Ohlson (1981) show that stock prices can rationally differ from "frictionless prices" by as much as transactions costs. Bhushan (1994), Hou and Moskowitz (2005) and Brav and Heaton (2006) argue that stock price is negatively related to commissions and shows that the magnitude of the drift is positively correlated with the degree of trading frictions. However, Battalio and Mendenhall (2007) contradict Bhushan's (1994) inference that the drift is bounded by transactions costs. ${ }^{6} \mathrm{Ng}$ et al. (2008) study how transaction costs explain the existence of the PEAD effect. Chordia et al. (2009) also document that the PEAD occurs mainly in highly illiquid stocks. ${ }^{7}$

\section{Divergence of opinion and PEAD}

A stream of finance literature offers a potential explanation of return patterns following company events: divergence among investors' opinions (Miller, 1977; Varian, 1985; Harris and Raviv, 1993; and Hong and Stein, 1999). ${ }^{8}$ Bamber (1987), Bamber et al. (1999), and Ajinkya et

The authors investigate the impact of liquidity costs on the drift by examining actual quotes available to investors and their results show that an investor could have earned hedged portfolio returns of at least $14 \%$ per year after trading costs between 1993 and 2002.

$\mathrm{Ng}$ et al. (2008) predict that an underreaction to earnings announcement can occur because transaction costs constrain profitable trades and the drift in returns after earnings surprises is larger for firms whose shares have higher transaction costs. Consistent with predictions, these authors find that earnings response coefficients are lower for firms with higher transaction costs and the profits of implementing the PEAD trading strategy are significantly reduced by transaction costs. Chordia et al. (2009) show a difference of $1.55 \%$ in returns per month between the most liquid stocks and the most illiquid stocks. The explanation is that illiquid stocks have high trading and market impact costs. The authors also show that transaction costs account for anywhere from $66 \%$ to $100 \%$ of the paper profits from the long-short strategy.

Harris and Raviv (1993) state that even though investors receive the same public information in an earnings announcement, but they interpret information differently. Kim and Verrecchia (1994) document that earnings announcements may increase information asymmetries because different market participants process announcement information differently in private or informed judgment, which causes greater divergence of opinions and leads to an increase in trading volume. Kandel and Pearson (1995) predict that, as a proxy for divergence of opinion, trading volume should increase around the earnings announcement dates. The authors find 
al. (2004) use trading volume around earnings announcements as a proxy for divergent opinions and find that volume is higher around those earnings announcements that are more likely to be associated with more divergent opinions.

Garfinkel and Sokobin (2006) provide a comprehensive study examining the relation between divergence of opinions and PEAD. They use unexpected trading volume as a proxy for divergence of opinion and find that unexpected trading volume around earnings announcements are positively related to future returns. In other words, a higher divergence of opinions at an earnings announcement date is associated with more positive returns during the post-earnings-announcement period. This evidence is consistent with Williams (1977), who predicts a positive association between future stock returns and divergence of opinion. In a more recent paper, Berkman et al. (2009) examine whether stocks with high differences of opinion have lower returns around earnings announcements. ${ }^{9}$

\section{DATA AND RESEARCH DESIGN}

The data used in this study are from two sources. First, from CSMAR, we obtain daily and monthly trading data and financial information for individual A-share stocks and the aggregated A-share market, including daily and monthly returns, daily trading volume, daily dollar trading volume, daily and monthly total market capitalization, and the daily and monthly market capitalization of tradable shares, as well as the risk-free rate. The market return is proxied by the daily or monthly aggregated market return constructed using A-share stocks listed on the SHSE and SZSE, and the risk-free rate is proxied by the daily or monthly return on the one-year fixed deposit. The accounting information used in this study is the book value of equity, which is defined as total shareholder equity. Second, from Bloomberg, we obtain the data for earnings announcement dates for A-share stocks from 2000 to 2008.

Our primary sample consists of earnings announcements between 2000 and 2008. All publicly listed firms in China are required to release quarterly announcements since the first quarter in 2002, and semi-annual reports since $2000 .{ }^{10}$ To examine whether there is a PEAD effect following earnings reports in the Chinese market, we examine all earnings announcement observations, including quarterly, semi-annual and annual earnings announcements. For our sample, if there are multiple announcements on the same day for the same firm, we retain a single observation of the earnings announcement date. From Bloomberg, we collect 48,265 observations for earnings announcement dates for Chinese A-share stocks. When we eliminate observations with missing variables, we are left with 32,711 observations in our sample. For the asset pricing tests, we use two samples to investigate whether PEAD is able to explain stock returns. One sample consists of A-share stocks that have PEAD data, that is, 1517 stocks with 88,962 observations. The other sample includes A-share stocks that have return data, that is, 1,660 stocks with 110,644 observations.

that volume is higher around earnings announcements than in non-announcement periods, in support of their prediction.

Berkman et al. (2009) use five proxies for divergence of opinion (earnings volatility, return volatility, dispersion of analysts' earnings forecasts, firm age, and share turnover) and find that stocks with a high divergence of opinion among investors have a price run-up prior to earnings announcements followed by a greater price reversal after the announcements. These findings favor Miller's (1977) hypothesis that stock prices which reflect an optimistic bias cannot persist indefinitely, in that periodic announcements that reduce differences of opinion also reduce upward bias in stock prices.

One interesting feature of the release of the earnings announcement date is that some listed firms release their annual and quarterly reports on the on the same day. For example, many listed firms in China release their annual reports of year $t$ and the first quarter announcements of year $t+1$ on the same day, sometimes even releasing the fourth-quarter announcements of year $t$, the annual announcements of year $t$, and the first-quarter announcements of year $t+1$ on the same day. 
We use the abnormal return at the earnings announcement as a measure of earnings surprise and proceed to investigate whether there is a PEAD effect. As discussed in the previous section, there are several potential determinants for the PEAD, including arbitrage risk, market risk, transaction costs and liquidity, divergence of opinion, short-sale constraints and investor sophistication. Short sales are not allowed in the Chinese stock market, so we are unable to construct a proxy for this factor. Due to the unavailability of data for investor holdings, this factor was also excluded. Hence, the variables used in this study are as follows.

\section{Earnings surprise}

In prior drift studies, a basic approach to estimating the earnings surprise is to use actual earnings minus a forecast of earnings divided by a deflator. The issue then is to determine the better proxy for earnings expectation. In general, there are two approaches. Researchers use either time series models based on COMPUSTAT data or analyst forecasts and actual earnings data from I/B/E/S. Our study uses the abnormal return to the earnings announcement as a measure of earnings surprise. There are several reasons: First, the available data for the analyst forecasts and actual earnings for Chinese A-share stocks from I/B/E/S are quite limited, and thus the I/B/E/S sample can be quite small. ${ }^{11}$ Second, firms listed in the Chinese market are required to release quarterly earnings announcement only since the first quarter in 2002. If we use a traditional time series model to calculate earnings surprise, this sample would be much smaller than if we use the abnormal return as the proxy of earnings surprise. Third, there is no theory to determine the best proxy for earnings surprise. For this reason, we follow Garfinkel and Sokobin (2006) to estimate earnings surprise based on abnormal returns at the earnings announcements.

Daily abnormal returns are the raw daily return minus the daily return on the market portfolio from the CSMAR. Here the CAR earnings announcement event window is the CAR for the threeday window $(t-1, t+1)$, where $t$ is the earnings announcement date. We define the immediate short-term earnings announcement returns (CAR) as

$$
C A R(-1,+1)_{i, e v e n t}=\sum_{t=-1}^{t=+1}\left(\text { ret }_{i, \text { event }, t}-R_{m, \text { even }, t}\right)
$$

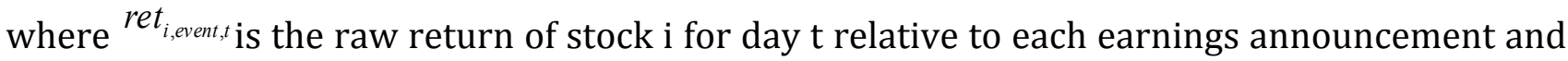
$R_{m, e v e n t, t}$ is the equal-weighted return of the market portfolio for day t relative to each earnings announcement. The event window $(t-1, t+1)$ includes one day before the earnings announcement date, the announcement date, and the following day.

\section{Post-earnings announcement abnormal returns}

Consistent with prior drift studies (e.g., Foster et al., 1984; Bernard and Thomas, 1989), we calculate drift the firm's abnormal return cumulated from two days after each announcement through a window of 60 trading days following the announcement, that is, $(t+2, t+60)$. The abnormal return is the raw return minus the average return on a market portfolio. The drift in returns following the earnings PEAD is defined as

${ }^{11}$ For Chinese A-share stocks, the I/B/E/S offers analysts forecast and actual earnings from 2004, but the number of forecasts is quite small, less than 700 . 


$$
P E A D_{i, \text { event }}=\sum_{t=2}^{t=60}\left(\text { ret }_{i, \text { event }, t}-R_{m, \text { event }, t}\right)
$$

where ret $_{i, \text { event }, t}$ and $R_{m, \text { event }, t}$ are defined as in model (5.1). The return period of drift PEAD $(t+$ $2, t+60$ ) runs from two day after each earnings announcement date over a period of 60 trading days.

\section{Control variables}

We use several control variables that prior literature investigates the relationship between them and post-earnings announcement drift. Hence, we discuss the reasons for each control variable in this section. First, we estimate arbitrage risk by regressing the individual stock return against the market return in the 24 months ending one month before earnings announcements. Market risk is the explained variance from the market model regression. Since in Mendenhall (2004), the author estimates a stock's arbitrage risk as the residual variance from a market model regression over the 48 months ending one month prior to the earnings announcement. Second and third, we use the closing stock price 20 days prior to earnings announcement (PRICE) and the daily closing price times daily shares traded averaged over -120 to -20 days relative to earnings announcements (VOLUME) as proxies for transaction cost and liquidity.

Bhushan (1994) and Mendenhall (2004) point out that transaction costs and liquidity play an important role in explaining PEAD and thus we also include transaction costs and liquidity in our study to investigate their explanatory power. Fourth, following Garfinkel and Sokobin (2006), we use unexpected trading volume (turnover) as a proxy for divergence of opinion, which is the difference between earnings announcement turnover and the turnover from a non-announcement period. A large market microstructure literature uses turnover as a proxy for liquidity. So here we use turnover to capture liquidity and divergence of opinion. Our measure of unexpected turnover is used to control for liquidity and to capture opinion divergence by subtracting daily market-adjusted turnover over a non-announcement period from that around the earnings announcement. Specifically, we first calculate daily turnover as the firm's trading volume on that day divided by its tradable shares outstanding, and market turnover is obtained by the same method. Thus, the average daily market-adjusted turnover around earnings announcement window $(t-1, t+1)$ is

$$
T O_{i, e a}=\frac{\sum_{t=-1}^{t=1}\left[\left(\frac{\text { Volume }_{i, t}}{\# \text { Shares }_{i, t}}\right)-\left(\frac{\text { MarketVolume }_{t}}{\# \text { MarketShares }_{t}}\right)\right]}{3}
$$

where Volume $_{i, t}$ is the trading volume for firm $i$ on day $t(t=0$ is the earnings announcement date), \#Shares ${ }_{i, t}$ is the number of shares outstanding for firm $i$ on day $t$, MarketVolume $e_{t}$ is the

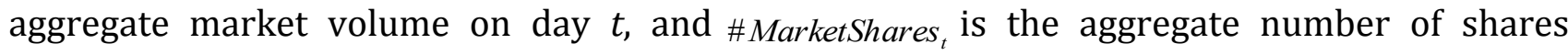
outstanding in the market on day $t$. We then calculate the turnover over non-earnings announcements as the market-adjusted turnover averaged over a pre-earnings announcement period from day -54 to day -5 relative to the earnings announcement. The difference between earnings announcement turnover and the turnover from a non-announcement period $\mathrm{TO}_{i, e a}$ is therefore 


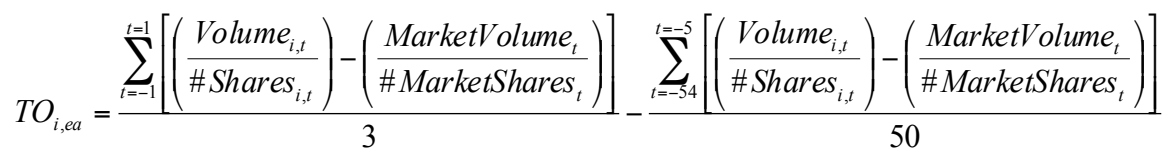

Fifth and sixth, we use market capitalization (SIZE) to control for the information environment of the firm (Grant, 1980; Bamber 1987; Shores 1990). Since for larger firms, accounting information may be richer and more quickly incorporated into stock prices. The size effect is documented for Chinese equities (Drew et al. 2003; Wang 2004). We use B/M in one month before earnings announcements. $\mathrm{B} / \mathrm{M}$ can be a proxy for risk and growth prospect. Those potential determinants of PEAD are summarized in Table 2.

Table 2

Earnings surprise measures and other potential determinants of post-earnings-announcement abnormal returns.

\begin{tabular}{|c|c|c|c|}
\hline Variable & Description & Proxy & $\begin{array}{l}\text { Expected } \\
\text { sign }\end{array}$ \\
\hline SUE & $\begin{array}{l}\text { Earnings surprise is based on abnormal returns at the earnings } \\
\text { announcements and daily abnormal returns are the raw daily } \\
\text { return minus the daily return on the market portfolio from the } \\
\text { CSMAR. }\end{array}$ & Earnings surprise & + \\
\hline Arbrisk & $\begin{array}{l}\text { Residual variance from market model regression estimated over } \\
24 \text { months ending one month prior to earnings announcement. } \\
\text { Source: CSMAR }\end{array}$ & Unexplained risk & + \\
\hline Mktrisk & $\begin{array}{l}\text { Explained variance from the market model regression. Source: } \\
\text { CSMAR }\end{array}$ & Explained risk & + or 0 \\
\hline Price & $\begin{array}{l}\text { Closing stock price } 20 \text { days prior to the earnings announcement. } \\
\text { Source: CSMAR }\end{array}$ & $\begin{array}{l}\text { Transaction } \\
\text { costs/liquidity }\end{array}$ & + \\
\hline Volume & $\begin{array}{l}\text { Daily closing price times daily shares traded averaged over }-120 \\
\text { to }-20 \text { days relative to earnings announcements. Source: CSMAR }\end{array}$ & $\begin{array}{l}\text { Transaction } \\
\text { costs/liquidity }\end{array}$ & + \\
\hline$\cdot$ TO & $\begin{array}{l}\text { Difference between earnings announcement turnover and the } \\
\text { turnover from a non-announcement period from day }-54 \text { to } \\
\text { day }-5 \text { relative to the earnings announcement. Source: CSMAR }\end{array}$ & Divergence of opinion & + \\
\hline SIZE & Market capitalization in year $t-1$. Source: CSMAR & $\begin{array}{l}\text { Information } \\
\text { environment/size } \\
\text { effect }\end{array}$ & - \\
\hline $\mathrm{B} / \mathrm{M}$ & Book-to-market ratio. Source: CSMAR & Growth/BM effect & + \\
\hline
\end{tabular}

This table provides a summary of earnings surprise measures and other potential determinants of post-earnings-announcement abnormal returns

\section{Research design \\ Portfolio analysis}

To investigate whether there is a PEAD in the Chinese stock market, we examine differences in returns on portfolios based on earnings surprise. Following Garfinkel and Sokobin (2006), we estimate earnings surprise based on the abnormal return at the earnings announcement. Thus, we sort stocks into 10 decile portfolios based on the CAR for the three-day window $(t-1, t+1)$ where $t$ is the earnings announcement date. We follow Bernard and Thomas (1990) and Bhushan (1994) and transform CARs at the earnings announcement dates into decile ranks by sorting firms into 10 groups and assigning a decile rank to each firm within each decile. The highest positive CARs are allocated in Decile 10 and the lowest negative CARs are assigned to Decile 1. The coded rank of each firm is the decile rank divided by 9 minus 0.5 . The ranks are then transformed to range between -0.5 to +0.5 . The average time series drift for each decile portfolio is then calculated from two days after an each announcement through a window 60 trading days following the announcement, that is, $(t+2, t+60)$. 


\section{Fama and MacBeth (1973) regression analysis}

We examine determinants of PEAD by estimating cross-sectional regressions of interactive variables. We run the Fama-MacBeth cross-sectional regressions to investigate the explanatory power of each variable. The model is as follows:

$$
\begin{aligned}
& \text { PEAD }(2,60)_{i}=\text { Intercept }+C_{A R R_{i, t}}+\text { CAR }_{i, t} * A R B R I S K_{i, t} \\
& + \text { CAR }_{i, t} * \text { MKTRISK }_{i, t}+\text { CAR }_{i, t} * \text { PRICE }_{i, t}+\text { CAR }_{i, t} * V_{i, t} \\
& +\operatorname{CAR}_{i, t} * \operatorname{SIZE}_{i, t}+C A R_{i, t} * B / M_{i, t}+C A R_{i, t} * \Delta T O_{i, t}
\end{aligned}
$$

\section{Asset pricing analysis}

To examine whether the PEAD is systematically priced as a risk factor, we run asset pricing tests on the CAPM one-factor, enhanced CAPM, and the FF three-factor and enhanced FF fourfactor models. We follow FF (1993) to construct the market, size and B/M factor-mimicking portfolios and the proxy for the new PEAD factor (HPEADMLPEAD). The variable HPEADMLPEAD is the average difference in abnormal returns between the top 30\% and bottom $30 \%$ of PEAD portfolios. Specifically, we calculate a PEAD factor-mimicking portfolio equal to the difference between the monthly excess returns of the top 30\% and the bottom $30 \%$ of portfolios. The asset pricing tests that include the PEAD factor as an additional independent variable allow us to assess the degree to which PEAD contributes to the market risk premium, size and B/M premiums in explaining returns. Our CAPM model is

$$
R_{i, t}-R_{f, t}=a_{p t}+b_{i}\left(R_{m t}-R_{f t}\right)+\varepsilon_{i, t}
$$

The enhanced CAPM model is

$$
R_{i, t}-R_{f, t}=a_{p t}+b_{i}\left(R_{m t}-R_{f t}\right)+p_{i} H P E A D M L P E A D_{t}+\varepsilon_{i, t}
$$

Our multifactor models of the FF three-factor model and enhanced FF four-factor models are

$$
\begin{gathered}
R_{i, t}-R_{f, t}=a_{p t}+b_{i}\left(R_{m t}-R_{f t}\right)+s_{i} S M B_{t}+h_{i} H M L_{t}+\varepsilon_{i, t} \\
R_{i, t}-R_{f, t}=a_{p t}+b_{i}\left(R_{m t}-R_{f t}\right)+s_{i} S M B_{t}+h_{i} H M L_{t}+p_{i} H P E A D M P E A D_{t}+\varepsilon_{i, t}
\end{gathered}
$$

where the dependent variable $\left(R_{i, t}-R_{f, t}\right)$ is the daily excess returns of individual stocks, $\left(R_{m, t}-R_{f, t}\right)$ is the excess daily return of the market portfolio, $S M B_{t}$ is the daily return on the zero-cost portfolio for size, $H M L_{t}$ is the daily return on the zero-cost portfolio for $\mathrm{B} / \mathrm{M}$, and HPEADMLPEAD ${ }_{t}$ is the daily return on the zero-cost portfolio for PEAD. The excess returns of individual stocks are regressed on each of the above asset pricing models (models 6 to 9) to determine whether the PEAD factor plays a significant role in explaining stock returns.

\section{Portfolio analysis}

\section{EMPIRICAL RESULTS}

Table 3 presents the means of CAR, PEAD, and characteristics for the period January 2000 to December 2008 for deciles sorted on CAR. Stocks are assigned to portfolios as described in the previous section. 
Table 3

Average of PEAD and characteristics for decile portfolios based on CAR

\begin{tabular}{|c|c|c|c|c|c|c|c|c|c|c|}
\hline \multicolumn{11}{|c|}{ Panel A: All earnings announcements sample } \\
\hline & $\mathrm{D}_{1}$ & $\mathrm{D}_{2}$ & $\mathrm{D}_{3}$ & $\mathrm{D}_{4}$ & $\mathrm{D}_{5}$ & $\mathrm{D}_{6}$ & $\mathrm{D}_{7}$ & $\mathrm{D}_{8}$ & $\mathrm{D}_{9}$ & $\mathrm{D}_{10}$ \\
\hline \multirow{3}{*}{ CAR } & - & - & - & - & - & - & & & & \\
\hline & 0.0951 & 0.0530 & 0.0355 & 0.0226 & 0.0118 & 0.0013 & 0.0097 & 0.0232 & 0.0435 & 0.1158 \\
\hline & & & - & - & & - & & & & \\
\hline PEAD & 0.0494 & 0.0468 & 0.0397 & 0.0312 & 0.0260 & 0.0185 & 0.0030 & 0.0125 & 0.0176 & 0.0298 \\
\hline \multicolumn{11}{|c|}{ Panel B: Firm characteristics of the decile portfolios } \\
\hline & $\mathrm{D}_{1}$ & $\mathrm{D}_{2}$ & $\mathrm{D}_{3}$ & $\mathrm{D}_{4}$ & $\mathrm{D}_{5}$ & $\mathrm{D}_{6}$ & $\mathrm{D}_{7}$ & $\mathrm{D}_{8}$ & $\mathrm{D}_{9}$ & $\mathrm{D}_{10}$ \\
\hline Size & 2,081 & 2,174 & 2,080 & 1,990 & 1,920 & 1,743 & 1,648 & 1,542 & 1,558 & 1,373 \\
\hline $\mathrm{B} / \mathrm{M}$ & 0.3857 & 0.3592 & 0.4261 & 0.4291 & 0.4079 & 0.4304 & 0.4086 & 0.4087 & 0.4068 & 0.4191 \\
\hline $\mathrm{D} / \mathrm{E}$ & 1.5699 & 1.3933 & 1.3365 & 1.4118 & 1.4269 & 1.2997 & 1.5310 & 1.3418 & 1.5177 & 1.7058 \\
\hline $\mathrm{S} / \mathrm{P}$ & 0.5303 & 0.5613 & 0.5548 & 0.5661 & 0.5460 & 0.5755 & 0.5465 & 0.5330 & 0.5153 & 0.5024 \\
\hline $\mathrm{E} / \mathrm{P}$ & $\overline{-} .0042$ & 0.0072 & 0.0116 & 0.0101 & 0.0159 & 0.0160 & 0.0152 & 0.0131 & 0.0141 & 0.0185 \\
\hline $\mathrm{C} / \mathrm{P}$ & 0.0281 & 0.0326 & 0.0356 & 0.0402 & 0.0377 & 0.0383 & 0.0384 & 0.0371 & 0.0341 & 0.0413 \\
\hline
\end{tabular}

Panel A of Table 3 represents the mean returns on 10 decile portfolios formed on earnings surprise which is based on the abnormal stock returns at the earnings announcement, CAR $(-1,+1)$. We follow Garfinkel and Sokobi $(2006)$ to calculate CAR $(-1,+1)$, which is the CAR from day -1 to day +1 relative to earnings announcements. Panel $\mathrm{B}$ of Table 3 reports the firm characteristics of each decile portfolios, including size, $\mathrm{B} / \mathrm{M}$, leverage, $\mathrm{S} / \mathrm{P}, \mathrm{E} / \mathrm{P}$ and $\mathrm{C} / \mathrm{P}$

Panel A of Table 3 presents the averages of CAR around earnings announcement and PEAD from day 2 to day 60 relative to the earnings announcement for 10 portfolios formed on CAR. Panel A of Table 3 reveals that there is a positive relationship between earnings surprise and PEAD: On average, the lowest-CAR decile $\left(\mathrm{D}_{1}\right)$ has a CAR of $-9.51 \%$ and a PEAD of $-4.94 \%$, while the highest-CAR decile $\left(\mathrm{D}_{10}\right)$ has a CAR of $11.58 \%$ and a PEAD of $2.98 \%$, a relative CAR difference of $21.09 \%\left(\mathrm{D}_{10}-\mathrm{D}_{1}\right)$ and $7.92 \%$ of PEAD. This delay in the stock price response to earnings announcements is consistent with the findings for developed markets because this delay is positive (negative) abnormal stock price performance following a better (worse) than expected earnings announcement.

Panel B of Table 3 presents the characteristics for portfolios, sorting on CAR. Interestingly, we find that, on average, stocks with larger CARs always have higher ratios of fundamental variables, such as $\mathrm{B} / \mathrm{M}$, leverage, $\mathrm{S} / \mathrm{P}, \mathrm{E} / \mathrm{P}$, and $\mathrm{C} / \mathrm{P}$. Thus, it appears that stocks that have larger earnings surprise are more likely to be value stocks. Table 4 reports the descriptive statistics for the explanatory variables of PEAD used in this study. Table 5 presents the correlations between the potential determinants of PEAD. Here CAR and PEAD are positively correlated, at 0.0699 , and PEAD is also correlated to ARBRISK and $\triangle$ TO but negatively correlated to other variables. CAR has a negative correlation with PRICE and VOLUME but is positively correlated with other variables. Since the correlations between PEAD and these explanatory variables are quite low, a regression analysis is required to investigate the impact of the potential determinants on PEAD. 
Table 4

Descriptive statistics for the explanatory variables of PEAD

\begin{tabular}{llllll}
\hline Variable & Mean & STD & $25 \%$ & Median & $75 \%$ \\
\hline CAR & 0.0021 & 0.1856 & -0.0328 & -0.0036 & 0.0250 \\
ARBRISK & 0.0084 & 0.9701 & 0.0052 & 0.0099 & 0.0209 \\
MKTRISK & 0.3959 & 1.1166 & 0.1484 & 0.2435 & 0.4227 \\
PRICE & 10.05 & 8.99 & 5.11 & 7.82 & 12.08 \\
VOLUME & 39,965 & 100,336 & 5,470 & 13,235 & 36,500 \\
SIZE & 1,825 & 5,788 & 467 & 824 & 1,593 \\
B/M & 0.4104 & 0.2827 & 0.2072 & 0.3422 & 0.5407 \\
$\cdot$ TO & 0.0020 & 0.0258 & -0.0066 & -0.0003 & 0.0072 \\
\hline
\end{tabular}

This table reports descriptive statistics for the explanatory variables used in this study to explain PEAD. Here CAR $(-1,+1)$ is the CAR from day -1 to day +1 relative to earnings announcements. ARBRISK is the residual variance from a market model regression of monthly individual stock return against market return over 48 months ending one month prior to earnings announcements. MKTRISK is the return variance explained by the market model regression: PRICE is the closing stock price 20 days prior to the earnings announcements; VOLUME is the average dollar trading volume from day -120 to day -20 relative to earnings announcements (in millions of RMB); SIZE is the market capitalization in the one month prior to earnings announcement (in millions of RMB); $\mathrm{B} / \mathrm{M}$ is the ratio of the book value of equity to market capitalization; and - TO is a proxy for divergence of opinion as described in this section.

Table 5

Correlation between potential explanatory variables of PEAD

\begin{tabular}{|c|c|c|c|c|c|c|c|c|c|}
\hline & $\begin{array}{c}\text { PEAD } \\
(+2,60)\end{array}$ & $\begin{array}{l}\text { CAR } \\
(-1,+1)\end{array}$ & $\begin{array}{l}\text { ARB } \\
\text { RISK }\end{array}$ & $\begin{array}{l}\text { MKT } \\
\text { RISK }\end{array}$ & PRICE & VOLUME & SIZE & $\mathrm{B} / \mathrm{M}$ & $\cdot$ TO \\
\hline $\begin{array}{l}\text { PEAD } \\
(+2,60)\end{array}$ & 1.0000 & & & & & & & & \\
\hline $\begin{array}{l}\text { CAR } \\
(-1,+1)\end{array}$ & 0.0699 & 10000 & & & & & & & \\
\hline ARBRISK & 0.0078 & 0.0021 & 1.0000 & & & & & & \\
\hline MKTRISK & & & & & & & & & \\
\hline PRICE & $\begin{array}{r}0.0060 \\
\text { - }\end{array}$ & 0.0035 & 0.4598 & 1.0000 & & & & & \\
\hline VOLUME & 0.0632 & 0.0077 & 0.0601 & 0.0763 & 1.0000 & & & & \\
\hline & 0.1104 & 0.0240 & 0.0150 & 0.0410 & 0.2990 & 1.0000 & & & \\
\hline SIZE & $0.0448^{-}$ & 0.0138 & $\begin{array}{r}- \\
0.0107\end{array}$ & 0.0091 & 0.3271 & 0.7815 & $\begin{array}{r}1.0000 \\
-\end{array}$ & & \\
\hline $\mathrm{B} / \mathrm{M}$ & 0.0764 & 0.0118 & 0.0550 & 0.0990 & 0.4701 & -0.1814 & 0.1273 & 1.0000 & \\
\hline$\cdot$ TO & $\begin{array}{r}- \\
0.0158\end{array}$ & 0.1337 & $\begin{array}{r}- \\
0.0064\end{array}$ & $\begin{array}{r}- \\
0.0147\end{array}$ & 0.0508 & -0.0087 & 0.0353 & 0.0144 & 1.0000 \\
\hline
\end{tabular}

This table presents Pearson correlation between the variables. Here PEAD $(+2,60)$ is the CAR from day +2 to day +60 relative to earnings announcements. Daily abnormal return is the difference between the daily return of individual stock and the market return. Here CAR $(-1$, +1 ) is the CAR from day -1 to day +1 relative to earnings announcements: ARBRISK is the residual variance from a market model regression of monthly individual stock returns against market return over 48 months, ending one month prior to earnings announcements; MKTRISK is the return variance explained by the market model regression; PRICE is the closing stock price 20 days prior to the earnings announcements; VOLUME is the average dollar trading volume from day -120 to day -20 relative to earnings announcements; SIZE is the market 
capitalization in the one month prior to earnings announcement. B/M is the ratio of the book value of equity to market capitalization; and $\cdot \mathrm{TO}$ is a proxy for divergence of opinion.

\section{Fama-MacBeth regression results}

To investigate how explanatory variables can affect the magnitude of the drift, we follow Bhushan (1994) and Bartov et al. (2000) to use interactive variables and the slope of the CARPEAD relation to vary with each potential determinant. We interpret the coefficient of each interactive variable as the average difference in abnormal returns between the highest and lowest CAR, since a regression slope coefficient is the expected change in the dependent variable for one unit change in the independent variable.

In Table 6, we present the Fama-MacBeth univariate regression results. For the regression of PEAD on the CAR, the average slope is 0.0103 and significant with a $t$-statistic of 2.04. This coefficient for CAR is consistently positive and statistically significant from zero at $5 \%$ level. We note that in Table 6 the drift is significantly negative related with market risk (MKTRISK), but positively related with VOLUME. The coefficient for the interactive variable CAR*MKTBRISK is -0.0275 , with a significant $t$-statistic -2.77 . The coefficient for the interactive variable CAR*VOL is 0.0264 , with a significant $t$-statistic 1.96 . The variables ARBRISK, PRICE, SIZE, B/M and divergence of opinion do not appear to add significant explanatory power for the PEAD. In summary, from the analysis of Fama-MacBeth regressions, we find that (1) the CAR is significantly and positively related to PEAD, which confirms the findings of portfolio analysis; (2) the factor of market risk is negatively related to PEAD; and (3) the factor of volume is positively related to PEAD. Full model regressions in Table 6 are repeated using a pool regression method in Table 7. The coefficients of CAR are negative and insignificant. With the exception of the significant coefficient for MKTRISK, all other coefficients are also insignificant.

Table 6

Fama-MacBeth univariate regression results of the potential explanatory variables for the PEAD

\begin{tabular}{|c|c|c|c|c|c|c|c|c|c|}
\hline Model & Intercept & CAR & $\begin{array}{c}\text { CAR } \\
\text { *ARB }\end{array}$ & $\begin{array}{c}\text { CAR } \\
{ }^{*} \mathrm{MKT}\end{array}$ & $\begin{array}{c}\text { CAR } \\
* \text { PRICE }\end{array}$ & $\begin{array}{l}\text { CAR } \\
\text { *VOL }\end{array}$ & $\begin{array}{l}\text { CAR } \\
{ }^{*} \text { SIZE }\end{array}$ & $\begin{array}{c}\text { CAR } \\
* \mathrm{~B} / \mathrm{M}\end{array}$ & $\begin{array}{l}\text { CAR } \\
* \cdot \text { TO }\end{array}$ \\
\hline 1 & $\begin{array}{l}-0.0073 \\
(-1.86)\end{array}$ & $\begin{array}{l}0.0103 \\
(2.04)\end{array}$ & & & & & & & \\
\hline 2 & $\begin{array}{l}-0.0074 \\
(-1.87)\end{array}$ & $\begin{array}{l}0.0103 \\
(1.97)\end{array}$ & $\begin{array}{l}0.0093 \\
(-0.80)\end{array}$ & & & & & & \\
\hline 3 & $\begin{array}{l}-0.0073 \\
(-1.89)\end{array}$ & $\begin{array}{l}0.0104 \\
(2.05)\end{array}$ & & $\begin{array}{l}0.0275 \\
(-2.77)\end{array}$ & & & & & \\
\hline 4 & $\begin{array}{l}-0.0070 \\
(-1.77)\end{array}$ & $\begin{array}{l}0.0102 \\
(2.01)\end{array}$ & & & $\begin{array}{l}0.0011 \\
(0.07)\end{array}$ & & & & \\
\hline 5 & $\begin{array}{l}-0.0074 \\
(-1.88)\end{array}$ & $\begin{array}{l}0.0101 \\
(2.03)\end{array}$ & & & & $\begin{array}{l}0.0264 \\
(1.96)\end{array}$ & & & \\
\hline 6 & $\begin{array}{l}-0.0076 \\
(-1.96)\end{array}$ & $\begin{array}{l}0.0104 \\
(2.04)\end{array}$ & & & & & $\begin{array}{l}0.0174 \\
(1.40)\end{array}$ & & \\
\hline 7 & $\begin{array}{l}-0.0072 \\
(-1.80)\end{array}$ & $\begin{array}{l}0.0100 \\
(1.91)\end{array}$ & & & & & & $\begin{array}{l}0.0133 \\
(-0.64)\end{array}$ & \\
\hline 8 & $\begin{array}{l}-0.0069 \\
(-1.66) \\
\end{array}$ & $\begin{array}{l}0.0119 \\
(2.68)\end{array}$ & & & & & & & $\begin{array}{l}0.0178 \\
(-0.89)\end{array}$ \\
\hline
\end{tabular}


This table represents the results of the Fama-MacBeth regressions estimated every quarter and the coefficients are averaged across all estimates. T-statistics are in PEAD $(+2,60)$ is the CAR from day +2 to day +60 relative to earnings announcements. Daily abnormal return is the difference between the daily return of an individual stock and the market return. CAR $(-1,+1)$ is the CAR from day -1 to day +1 relative to earnings announcements: ARBRISK is the residual variance from a market model regression of a monthly individual stock return against market return over 48 months ending one month prior to earnings announcements; MKTRISK is the return variance explained by the market model regression; PRICE is the closing stock price 20 days prior to the earnings announcements; VOLUME is the average dollar trading volume from day -120 to day -20 relative to earnings announcements; SIZE is the market capitalization in the one month prior to earnings announcement. $\mathrm{B} / \mathrm{M}$ is the ratio of the book value of equity to market capitalization; and -TO is a proxy for divergence of opinion. All independent variables are ranked into deciles that are then adjusted by dividing the ranks by 9 and subtracting 0.5 , such that the coded rankings range from -0.5 to 0.5

Table 7

Pooled univariate regression results of the potential explanatory variables for the PEAD

\begin{tabular}{|c|c|c|c|c|c|c|c|c|c|}
\hline Model & Intercept & CAR & $\begin{array}{l}\text { CAR } \\
\text { *ARBRISK }\end{array}$ & $\begin{array}{l}\text { CAR } \\
{ }^{*} \text { MKTRISK }\end{array}$ & $\begin{array}{l}\text { CAR } \\
\text { *PRICE }\end{array}$ & $\begin{array}{l}\text { CAR } \\
* \text { VOL }\end{array}$ & $\begin{array}{l}\text { CAR } \\
* \text { SIZE }\end{array}$ & $\begin{array}{l}\text { CAR } \\
*^{B} / \mathrm{M}\end{array}$ & $\begin{array}{l}\text { CAR } \\
* \text { *TO }\end{array}$ \\
\hline 1 & $\begin{array}{l}-0.02872 \\
(-20.70)\end{array}$ & $\begin{array}{l}-0.00080 \\
(-0.18)\end{array}$ & & & & & & & \\
\hline 2 & $\begin{array}{l}-0.02873 \\
(-20.71)\end{array}$ & $\begin{array}{l}-0.00069 \\
(-0.16)\end{array}$ & $\begin{array}{l}-0.00680 \\
(-0.49)\end{array}$ & & & & & & \\
\hline 3 & $\begin{array}{l}-0.02878 \\
(-20.75)\end{array}$ & $\begin{array}{l}-0.00051 \\
(-0.12)\end{array}$ & & $\begin{array}{l}-0.03384 \\
(-2.50)\end{array}$ & & & & & \\
\hline 4 & $\begin{array}{l}-0.02876 \\
(-20.73)\end{array}$ & $\begin{array}{l}-0.00106 \\
(-0.24)\end{array}$ & & & $\begin{array}{l}0.02161 \\
(1.60)\end{array}$ & & & & \\
\hline 5 & $\begin{array}{l}-0.02871 \\
(-20.70)\end{array}$ & $\begin{array}{l}-0.00097 \\
(-0.22)\end{array}$ & & & & $\begin{array}{l}0.02090 \\
(1.53)\end{array}$ & & & \\
\hline 6 & $\begin{array}{l}-0.02878 \\
(-20.74)\end{array}$ & $\begin{array}{l}-0.00063 \\
(-0.15)\end{array}$ & & & & & $\begin{array}{l}0.01871 \\
(1.38)\end{array}$ & & \\
\hline 7 & $\begin{array}{l}-0.02871 \\
(-20.70)\end{array}$ & $\begin{array}{l}-0.00097 \\
(-0.22)\end{array}$ & & & & & & $\begin{array}{l}-0.00777 \\
(-0.57)\end{array}$ & \\
\hline 8 & $\begin{array}{l}-0.02882 \\
(-20.64)\end{array}$ & $\begin{array}{l}-0.00116 \\
(-0.27)\end{array}$ & & & & & & & $\begin{array}{l}0.00836 \\
(0.64)\end{array}$ \\
\hline
\end{tabular}

This table represents the pooled univariate regressions of the relationship between explanatory variables and PEAD. PEAD $(+2,60)$ is the CAR from day +2 to day +60 relative to earnings announcements. Daily abnormal return is the difference between the daily return of an individual stock and the market return. Here $\operatorname{CAR}(-1,+1)$ is the cumulative abnormal returns from day -1 to day +1 relative to earnings announcements: ARBRISK is the residual variance from a market model regression of a monthly individual stock return against market return over 48 months ending one month prior to earnings announcements. MKTRISK is the return variance explained by the market model regression; PRICE is the closing stock price 20 days prior to the earnings announcements; VOLUME is the average dollar trading volume from day -120 to day -20 relative to earnings announcements; SIZE is the market capitalization in the one month prior to earnings announcement. $\mathrm{B} / \mathrm{M}$ is the ratio of the book value of equity to market capitalization; and -TO is a proxy for divergence of opinion. All independent variables are ranked into deciles which are then adjusted by dividing the ranks by 9 and subtracting 0.5 , such that the coded rankings range from -0.5 to 0.5 . 


\section{Asset pricing test results}

We investigate whether a PEAD is systematically priced as a risk factor in stock returns. We examine the significance of PEAD in the context of the one-factor and three-factor asset pricing models, as well as the enhanced one-factor and three-factor asset pricing models. Table 8 reports the mean values of the coefficients and $t$-statistics for whether the mean coefficient is significantly different from zero. We begin by estimating the traditional CAPM and then add a new factor, HPEADMLPEAD. The coefficient for the new factor HPEADMLPEAD, is positive and highly statistically significant, with a $t$-statistic of 18.21. Although the coefficient of beta remains positive and significant, its magnitude and significance have decreased. This suggests that some information in the PEAD factor overlaps with the market risk premium. Nonetheless, the evidence of both significant variables indicates that neither beta nor the PEAD factor can replace the other. We also investigate whether PEAD adds explanatory power to a multifactor asset pricing model by examining the enhanced FF three-factor model. This result provides evidence as to whether the PEAD factor proxies for either or both the size (SMB) and the B/M factors (HML). The coefficient for the PEAD factor is 0.3997, with a $t$-statistic of 11.79. This result confirms the explanatory power of the new PEAD factor in stock returns. The results in Table 8 confirm that PEAD plays a statistical role in pricing stock returns. To investigate whether these findings are specific to the sample of stocks used to calculate the PEAD factor, we repeat the one- and three-factor tests in Table 9. Specifically, the CAPM tests show significant positive loadings on the PEAD factor, with a $t$-statistic of 4.32. The three-factor results show that the PEAD factor retains statistical significance in relation to the other three factors ( $t$-statistic, 2.26).

Table 8

Regression analysis of the relation between expected stock returns and PEAD by testing the asset pricing models of the CAPM, the enhanced CAPM, and the FF three-factor and the enhanced FF three-factor models with a sample consisting of individual stocks that have earnings announcements data

\begin{tabular}{lllllllll}
\hline & \multicolumn{3}{l}{ Base model: CAPM } & \multicolumn{5}{l}{ Base model: FF 3-factor model } \\
\cline { 2 - 9 } & Coeff & $t$-Stat & Coeff & $t$-Stat & Coeff & $t$-Stat & Coeff & $t$-Stat \\
Intercept & & & - & - & & & & \\
$\mathrm{R}_{\mathrm{m}}-\mathrm{R}_{\mathrm{f}}$ & 0.0099 & 7.38 & 0.0072 & 3.87 & 0.0196 & 13.60 & 0.0151 & 4.29 \\
$\mathrm{SMB}$ & 0.6617 & 82.72 & 0.4542 & 2.23 & 0.6795 & 61.19 & 0.4762 & 2.07 \\
HML & & & & & 0.4951 & 29.87 & 0.5107 & 14.66 \\
HPEADMLPEAD & & & & & -0.1055 & -3.97 & 0.2866 & 2.03 \\
\hline
\end{tabular}

This table reports the coefficients and $t$-statistics for the asset pricing models including the CAPM, the enhanced CAPM, and the FF three-factor and enhanced FF three-factor models. The sample consists of the individual stocks that have earnings announcements data. We follow FF (1993) to define and measure the risk factors $R_{m}-R_{f}$, SMB and HML, where $R_{m}-R_{f}$ is excess return on the market portfolio; SMB is the return on the size factor-mimicking portfolio, HML is the return on the $\mathrm{B} / \mathrm{M}$ factor-mimicking portfolio; and HPEADMLPEAD is the return on the PEAD factor-mimicking portfolio. 


\section{Table 9}

Regression analysis of the relationship between expected stock returns and PEAD by testing the asset pricing models of the CAPM, the enhanced CAPM, and the FF three-factor and the enhanced FF three-factor models with the sample consisting of individual stocks that have return data Base-model: CAPM Base-model: FF three-factor model

\begin{tabular}{lllllllll} 
& Coeff & $t$-Stat & Coeff & $t$-Stat & Coeff & $t$-Stat & Coeff & $t$-Stat \\
Intercept & 0.0271 & 16.75 & 0.0312 & 10.75 & 0.0174 & 3.08 & 0.0290 & 10.36 \\
$\mathrm{R}_{\mathrm{m}}-\mathrm{R}_{\mathrm{f}}$ & 1.1603 & 96.65 & 1.1610 & 96.68 & 1.0456 & 82.78 & 1.0351 & 75.38 \\
SMB & & & & & 0.4807 & 6.60 & 0.6438 & 21.36 \\
HML & & & & & 0.2572 & 1.99 & 0.0688 & 1.12 \\
HPEADMLPEAD & & & 0.0897 & $\mathbf{4 . 3 2}$ & & & 0.0750 & $\mathbf{2 . 2 6}$ \\
\hline
\end{tabular}

This table reports the coefficients and $t$-statistics for the asset pricing models including the CAPM, the enhanced CAPM, and the FF three-factor and the enhanced FF three-factor model. The sample consists of the individual stocks that have stock return data. We follow FF (1993) to define and measure the risk factors $R_{m}-R_{f}, S M B$, and HML, where $R_{m}-R_{f}$ is excess return on the market portfolio; SMB is the return on the to size factor-mimicking portfolio, HML is the return on the $\mathrm{B} / \mathrm{M}$ factor-mimicking portfolio, and HPEADMLPEAD is the return on the PEAD factor-mimicking portfolio.

\section{CONCLUSIONS}

This study investigates the delay in the stock price response to earnings announcements in the Chinese stock market. Consistent with the findings of Truong (2011), we confirm a PEAD in the Chinese stock market by showing that the hedge trading strategy of going long on the top 10\% of earnings surprise stocks and short on the bottom $10 \%$ of earnings surprise stocks can generate $7.92 \%$ excess return in 60 days following the earnings announcement. Additionally, we examine potential determinants of the PEAD effect and find that the magnitude of PEAD is significantly negatively related to market risk. We also find evidence that the magnitude of the drift is positively related to trading volume as a proxy for transactions costs and liquidity. In the asset pricing tests, we find that the PEAD factor is significantly and positively priced as a risk factor, not only for the sample of stocks with PEAD data, but also for the sample of A-share stocks. To the best of our knowledge, this is the first study that examines whether the PEAD is a risk factor in China. The findings in this study have important implications for researchers and investors. For example, both domestic and global institute investors can conduct trading strategy based on earnings information in China. The significant role of the PEAD in explaining stock returns can help us understand stock price formation in an emerging market.

\section{References}

Abarbannell, J., Bernard V., 1992. Tests of analysts' overreaction/underreaction to earnings information as an explanation for anomalous stock price behavior. The Journal of Finance 47, 1181-1207.

Ajinkya, B., Atiase, R., Donth, A., Gift, M., 2004. Heterogeneous prior beliefs, differential interpretation and the consensus effect of quarterly earnings signals and trading volume. Working paper, University of Texas, Austin.

Ball, R., Brown, P., 1968. An empirical evaluation of accounting numbers. Journal of Accounting Research 6, 159178.

Ball, R., Bartov E., 1996. How na"ive is the stock market's use of earnings information? Journal of Accounting and Economics 21, 319-337.

Bartov, E., 1992. Patterns in unexpected earnings as an explanation for post-announcement drift. The Accounting Review 67, 610-622.

Bartov, E., Radhakrishnan, S., Krinsky I., 2000. Investor sophistication and patterns in stock returns after earnings announcements. Accounting Review 75, 43-63.

Battalio, R., Mendenhall, R., 2007. Post-earnings announcement drift: timing and liquidity costs. Working paper, University of Notre Dame, US. 
Beltratti, A., Bortolotti, B., 2006. The non-tradable share reform in the Chinese stock market. Working paper, University of Fondazione Eni Enrico Mattei, Italy.

Berkman, H., Dimitrov, V., Jain, P.C., Koch, P.D., Tice, S., 2009. Sell on the news: Difference of opinion, short-sales constraints and returns around earnings announcements. Journal of Financial Economics 92, 376-399.

Bernard, V. L., Thomas, J. K., 1989. Post-earnings-announcement drift, delayed price response or risk premium? Journal of Accounting Research 27, 1-48.

Bernard, V. L., Thomas, J. K., 1990. Evidence that stock prices do not fully reflect the implications of current earnings for future earnings. Journal of Accounting and Economics 13, 305-340.

Bhushan, R., 1994. An informational efficiency perspective on the post-earnings announcement drift. Journal of Accounting and Economics 18, 45-65.

Booth, G.G., Kallunki, J.-P., Martikainen, T., 1996. Post-earnings announcement drift and income smoothing: Finnish evidence. Journal of Business Finance and Accounting 23, 1197-1211.

Booth, G.G., Kallunki, J.-P., Martikainen, T., 1997. Delayed price response to the announcements of earnings and its components in Finland. European Accounting Review 6, 377-392.

Brown, P., Kennelly, 1972. The information content of quarterly earnings: An extension and some further evidence. Journal of Business 45, 403-415.

Chen, G., Kim, K.A., Nofsinger, J.R., Rui, O.M., 2007. Trading performance, disposition effect, overconfidence, representativeness bias, and experience of emerging market investors. Journal of Behavior Decision Making 18, $222-266$

Chen, S., Sun, S., Wu, D., 2010. Client importance, institutional improvements, and audit quality in China: an office and individual auditor level analysis. The Accounting Review 85, 127-158.

Chordia T., Goyal, A., Sadka, G., Sadka R., Shivakumar, L., 2009. Liquidity and the post-earnings announcement drift. Financial Analysts Journal 65, 18-32.

Diether, K.B., Malloy, C.J., Scherbina, A., 2002. Differences of opinion and the cross section of stock returns. Journal of Finance 57, 2113-2141.

Drew, M.E., Naughton, T., Veeraraghavan, M., 2003. Firm size, book to market equity and security returns: Evidence from the Shanghai Stock Exchange. Australian Journal of Management 28, 119-140.

Eun, C.S., Huang, W., 2007. Asset pricing in China's domestic stock markets: is there a logic? Pacific-Basin Finance Journal 15, 434-451.

Fama, E., French K., 1993. Common risk factors in the returns on stocks and bonds. Journal of Financial Economics $33,3-56$.

Fama, E. F., 1998. Market efficiency, long-term returns, and behavioral finance. Journal of Financial Economics 49, 283-306.

Foster, G., 1977. Quarterly accounting data: time-series properties and predictive-ability results. Accounting Review 52, 1-21.

Foster, G., Olsen C., Shevlin T., 1984. Earnings releases, anomalies and the behavior of security returns. The Accounting Review 59, 574-603.

Freeman, R., Tse, S., 1989. The multiperiod information content of accounting earnings: confirmations and contradictions of previous earnings reports. Journal of Accounting Research 27, 49-84.

Garfinkel, J., Sokobin J., 2006. Volume, opinion divergence, and returns: a study of post-earnings announcement drift. Journal of Accounting Research 44, 85-112.

Gong, W., 2003. Chines consumer behavior. Journal of American Academy Business 3, 373-380.

Grinblatt, M., and M. Keloharju. 2000. The investment behavior and performance of various investor types: a study of Finland's unique data set. Journal of Financial Economics 55, 43-67.

Hew, D., Skettatt, L., Strong, N., Walker, M., 1996. Post-earnings announcement drift: some preliminary evidence for the UK. Accounting and Business Research 26, 283-293.

Hirshleifer, D., J. Myers, L. Myers, and S. Teoh. 2008. Do individual investors cause post earnings announcement drift? Direct evidence from personal trades. The Accounting Review 83: 1521-1550. 
Jacob, J., Lys, T., Sabino, J., 2000. Autocorrelation structure of forecast errors from time-series models: Alternative assessments of the causes of post-earnings announcement drift. Journal of Accounting and Economics 28, 329358.

Jones, C., Litzenberger, R., 1970. Quarterly earnings reports and intermediate stock price trends. Journal of Finance 25, 143-148.

Joy, O., Litzenberger, R., McEnally, R., 1977. The adjustment of stock prices to announcements of unanticipated changes in quarterly earnings. Journal of Accounting Research 15, 207-225.

Kandel, E., Pearson, N., 1995. Differential interpretation of public signals and trade in speculative markets. Journal of Political Economy 103, 831-872.

Kang, J., Liu, M., Ni, X.S., 2002. Contrarian and momentum strategies in the China stock market: 1993-2000. Pacific-Basin Finance Journal 10, 243-265.

Kothari, S.P., 2001. Capital Market Research in Accounting. Journal of Accounting and Economics 31, $105-231$.

Kraft, A., 1999. Accounting-based and market-based trading rules. Working paper, University of Rochester.

Liu, W., Norman, S., Xinzhong X., 2003. Post-earnings announcement drift in the UK. European Financial Management 9, 89-116.

Livnat, J., Mendenhall, R. R., 2006. Comparing the post-earnings announcement drift for surprises calculated from analyst and time series forecasts. Journal of Accounting Research 44, 177-205.

Mande, V., Kwak, W., 1996. Do Japanese analysts overreact or underreact to earnings announcements? Abacus 32, 81-101.

Mendenhall, R. R., 2004. Arbitrage risk and post-earnings-announcement drift. Journal of Business 77, 875-894.

Miller E., 1977. Risk, uncertainty, and divergence of opinion. Journal of Finance 32, 1151-68.

Naughton, T., Truong, C., Veeraraghavan, M., 2008. Momentum strategies and stock returns: Chinese evidence. Pacific-Basin Finance Journal 16, 476-492.

$\mathrm{Ng}$, L., Wu, F., 2007. The trading behavior of institutions and individuals in Chinese equity markets. Journal of Banking \& Finance 31, 2695-2710.

Richardson, S., Irem, T., Wysocki, Pl, 2010. Accounting anomalies and fundamental analysis: a review of recent research advances. Journal of Accounting and Economics 50, 410-454.

Shleifer, A., Vishny, R., 1997. The limits of arbitrage. Journal of Finance 52, 35-55.

Sun, Q., Tong, W.H.S., 2003. China share issue privatization: the extent of its success. Journal of Financial Economics 70, 183-222.

Truong, C., 2010. Post earnings announcement drift and the roles of drift-enhanced factors in New Zealand. Pacific-Basin Finance Journal 18, 139-157.

Truong, C., 2011. Post-earnings announcement abnormal return in the Chinese equity market. Journal of International Financial Markets, Institutions \& Money, forthcoming.

Varian, Hal R., 1985. Divergence of opinion in complete markets: A note. Journal of Finance 40, 309-317.

Wang, C., 2004. Relative strength strategies in China's stock market: 1994-2000. Pacific-Basin Finance Journal 12, 159-177.

Wang, F., Xu, Y., 2004. What determines Chinese stock returns? Financial Analysts Journal 60, 65-77.

Wurgler, J., Zhuravskaya, K., 2002. Does arbitrage flatten demand curves for stocks? Journal of Business 75, 583608. 